\title{
Detection of heat shock protein 70 in choroidal neovascular membranes secondary to age related macular degeneration
}

\author{
Andreas PW Jöres ${ }^{1 *}$, Dörthe Carstesen ${ }^{1}$, Gabriele Thumann ${ }^{1}$, Peter Walter ${ }^{1}$ and Andreas WA Weinberger ${ }^{1,2}$
}

\begin{abstract}
Background: Heat shock proteins are acute phase proteins that are upregulated in inflammation or following thermal stress. We analyzed the presence of the heat shock protein 70 (Hsp 70) in choroidal neovascular (CNV) membranes secondary to AMD after treatment with verteporphin photodynamic therapy (PDT) or transpupillary thermo therapy (TT) to determine whether treatment correlated with the presence of Hsp70.

Results: CNV membranes were removed by pars plana vitrectomy (ppV) and subretinal extraction. The membranes were analysed by light microscopy and the presence of Hsp 70 was examined using histochemistry. HeLa Cells served as controls.

Of the 14 membranes analysed 11 were Hsp70 positive and 3 negative. In the no pre-treatment group of 8 membranes 6 were Hsp70 positive and 2 negative; in the PTD group all 4 membranes were positive and in the TाT group 1 membrane was positive and 1 membrane was negative for Hsp70.

Conclusion: Hsp70 is present in the most CNV membranes secondary to AMD. Pre-treatment of the membrane with PTD or TIT does not appear to influence the expression of Hsp70.
\end{abstract}

\section{Background}

Choroidal neovascularization (CNV) is the leading cause of severe visual impairment in patients with agerelated macular degeneration (AMD) since when left untreated $\mathrm{CNV}$ leads to disciform scarring of the macula $[1,2]$.

Several therapeutic strategies have been attempted to reduce the destructive effects of $\mathrm{CNV}$ membranes and stabilize vision. Since 2006 the preferred treatment for neovascular AMD is the intravitreal injections of inhibitors of VGF's especially the monoclonal antibodies bevacizumab $\left(\right.$ Avastin $\left.^{\circledR}\right)$ and ranibizumab (Lucentis $\left.{ }^{\circledR}\right)[3,4]$. Photodynamic therapy (PDT), submacular surgery and laser procedures have become second line options. While argon laser photocoagulation destroys the CNV and overlying retina, transpupillary thermotherapy (TTT) has been thought to selectively damage the CNV

\footnotetext{
* Correspondence: andreas.joeres@gmx.de

${ }^{1}$ RWTH Aachen University, Department of Ophthalmology, Pauwelsstr. 30, 52074 Aachen, Germany

Full list of author information is available at the end of the article
}

by hyperthermia, inducing thrombotic vessel occlusion while sparing the overlying retina [5].

Heat shock proteins function as intra-cellular chaperones for other proteins and play a critical role in protein-protein interactions, assist in generating proper protein conformation and prevent pathological protein aggregation. Hsp proteins are expressed under physiological condition in all organisms and play an essential role in protein maintenance $[6,7]$.

Hsp70's are a family of proteins that, as other heat shock proteins, aid in protein folding and stabilization. Hsp70's have been extensively investigated and are overexpressed under conditions of stress and serve to protect proteins from damage during stress $[8,9]$.

Hsp70 is present in the retina [10] and Desmettre et al. [11] has shown that application of subtreshold transpupillary TTT irradiation induces overexpression of Hsp70 in a rabbit model of CNV. Here we have investigated whether CNV membranes from AMD patients express Hsp70 and whether the expression is modulated by pre-treatment with TTT or PDT.
C Biomed Central

๑ 2011 Jöres et al; licensee BioMed Central Ltd. This is an Open Access article distributed under the terms of the Creative Commons Attribution License (http://creativecommons.org/licenses/by/2.0), which permits unrestricted use, distribution, and reproduction in any medium, provided the original work is properly cited. 


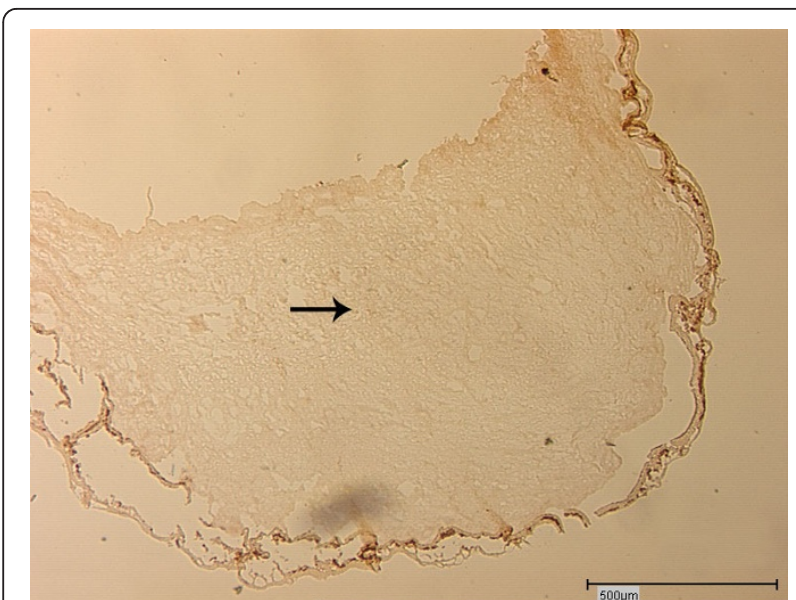

Figure 1 Native cnv membrane. Native cnv membrane (bright field, magnification $5 \times$ ). Arrow indicates fibrovascular tissue.

\section{Methods}

Subretinal CNV tissue (Figure 1) was removed by pars plana vitrectomy and maintained at $-24^{\circ} \mathrm{C}$ until use. The CNV tissue was embedded in Jung's medium and sectioned in $5 \mu \mathrm{m}$ thick sections using a cryostat (Leitz Lauda Kryostat 1720 Digital). The sections were mounted on SuperFrost Plus glass slides, incubated with blocking solution (5\% BSA in PBS) for 1 hour at room temperature in a humidified chamber followed by incubation with an anti-Hsp/Hsc70 monoclonal antibody (Chemicon ${ }^{\circledR}$ International, Lot: 24060368). After overnight incubation at $4^{\circ} \mathrm{C}$ (or 1 hour at $37^{\circ} \mathrm{C}$ ) the sections and HeLa cells (atcc number: CCL-2, LGC Promochem) were washed with PBS (Tween 20) 2 times for 5 minutes and incubated for 1 hour with a biotinylated antimouse secondary antibody (Polylink, Lot: C036, DCS Innovative Diagnostic Systems). After washing twice for 5 minutes with PBS (Tween 20) the sections and the
HeLa cells were incubated with streptavidin-alkaline phosphatase for $30 \mathrm{~min}$ at room temperature followed by $2 \times 5$ minutes washes with PBS (tween 20), followed by incubation with the chromogenic alkaline phosphatase. An avidin-biotin blocking kit was used to inhibit endogenous avidin and biotin (BioGenex Laboratories). To inhibit endogenous alkaline phosphatase levamisol was used (Dako ${ }^{\mathbb{R}}$ ).

For negative controls (Figure 2), the primary antibody was replaced by PBS. CNV membranes were stained with Celestine and Eosin and embedded in Imagen embedding medium (Dako Cytomation). Due to broad spectrum tissue autofluorescene labeled antibodies could not be used (Figure 3).

For light microscopic evaluation a Leica DM IRB microscope was used. Images were captured with a microscope-mounted camera (Hitachi 3CCD HV-C20 AMP Color Camera) and processed with the PC software, DISKUS microscopic documentation (Hilgers, Germany).

\section{Results}

Of the fourteen CNV membranes from fourteen patients (7 female 72,5 $\pm 11,5$ years and 6 male 73,5 $\pm 10,5$ years) with AMD examined for the presence of Hsp/ Hsc70, eleven membranes were Hsp70 positive, whereas 3 were Hsp/Hsc70 negative. The four membranes obtained from PDT pre-treated patients were all positive for Hsp/Hsc70 (Figure 4a, b) whereas of the two membranes obtained from TTT pre-treated patients one was positive and one was negative (Figure $4 \mathrm{c}, \mathrm{d}$ ). Of the eight membranes obtained from non-treated patient six were positive for $\mathrm{Hsp} / \mathrm{Hsc70}$ and two were negative (Figure 4e, f).

In summary $79 \%$ of the fourteen membranes examined Hsp/Hsc70 positive.

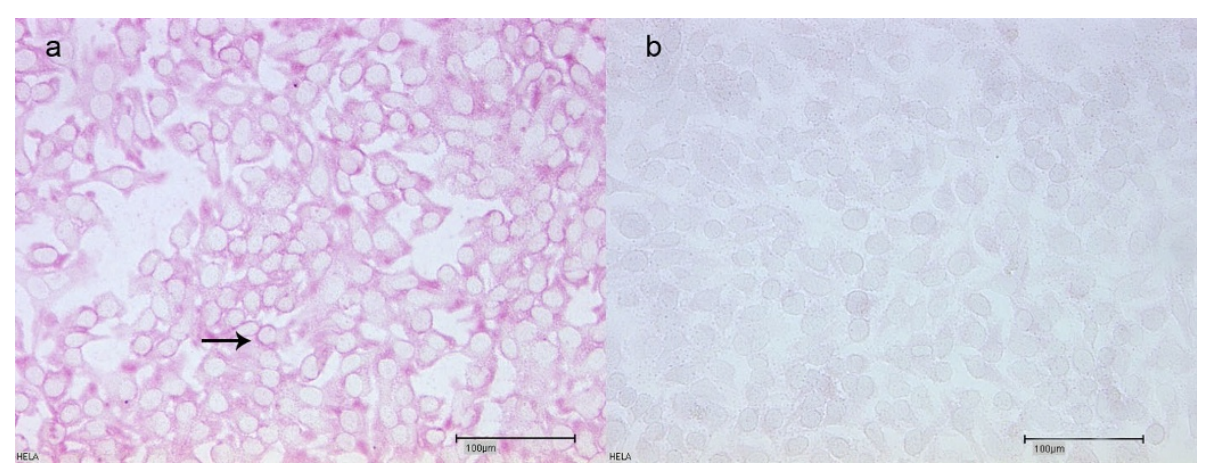

Figure 2 HeLa Cells - HeLa Cells served as positive controls. a) Nearly confluently growing cells. As primary antibody Anti Hsp 70 was used. Pink staining verifies presence of Hsp 70 (magnification 20x). Arrow: It appears that Hsp is localized mostly on the nuclear membrane. b) No primary antibody was used. Missing immunoreactivity verifies antibody specifity (magnification $20 \mathrm{x}$ ). 


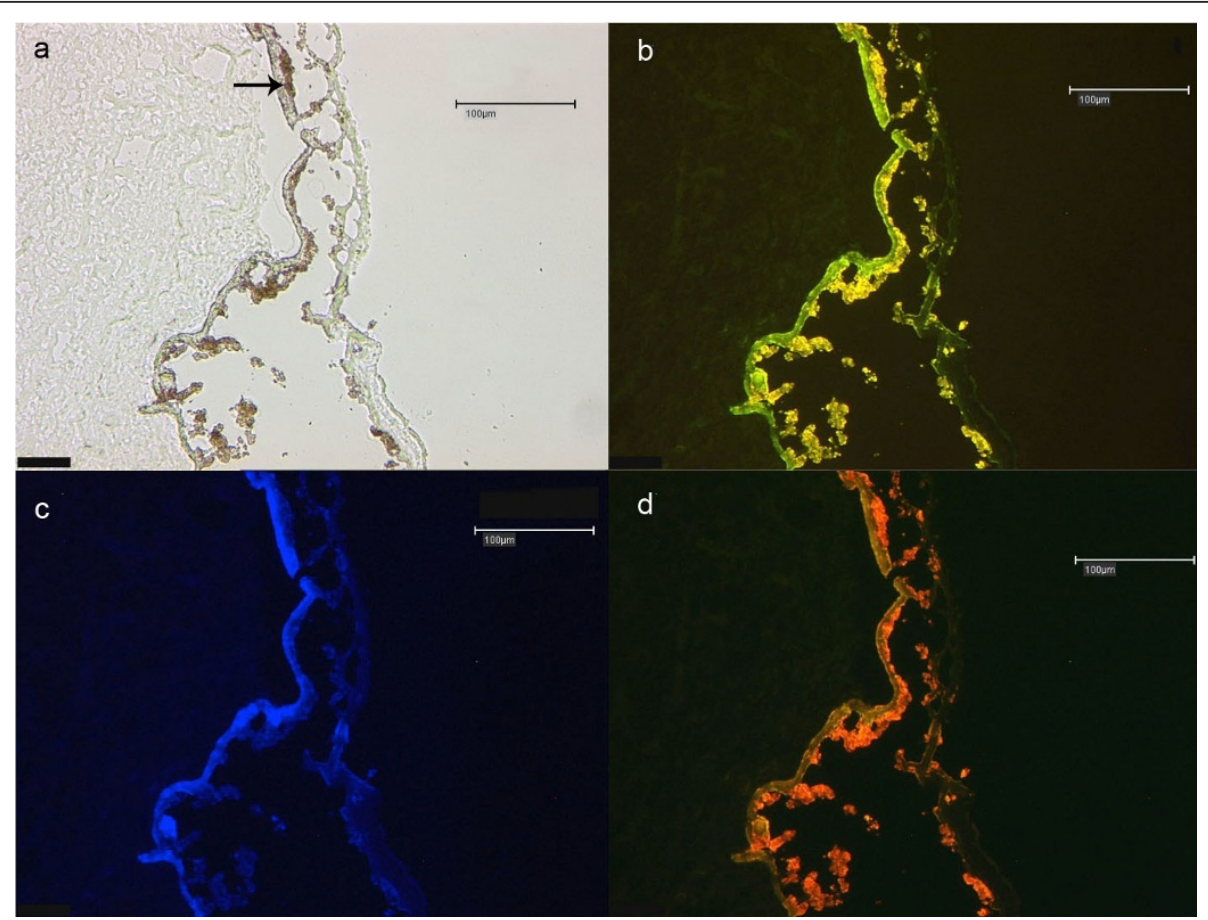

Figure 3 Tissue autofluorescence. $a-d$ ) These figures show four non treated (native) CNV membranes at20 $\times$ magnification. a) Shows bright field and Fig 3b-d the autofluorescence of lipofuscin in red, green and blue field. Although different wave length were used, tissue autofluorescence is present at various wavelengths so that nucleus staining (DAPI) and Hsp70-detection could not be performed. Arrow indicates the retinal pigment epithelium (RPE).

\section{Discussion and conclusions}

The presence of Hsc70/Hsp70 has been described in the normal retina. Dean et al. [5] have shown that Hsc70 immunoreactivity was present in all layers of the retina, except in the photoreceptor outer segments and the retinal pigment epithelium (RPE) whereas Hsp70 immunoreactivity was restricted to the inner segments of photoreceptors, the membrana limitans externa and the outer nuclear layer. Dean et al. have suggested that different eye structures are dependent on different and specific heat shock proteins [12]. In our laboratory we have found that Hsp70 is normally present in all retinal layers, except the retinal pigment epithelium.

In this study Hsp70 was detected in the majority of $\mathrm{CNV}$ membranes secondary to AMD. The presence of significant amounts of Hsp70 in the CNV membranes indicates that the cellular components of the membranes are cells (fiboblasts, endothelial cells, RPE cells, etc.) that have been subjected to a stressful environment and inflammatory responses induced by $\mathrm{CNV}$ membrane in its surrounding tissue. Furthermore, heat shock proteins have been detected in various retinal layers in animal models, indicating a physiologic role in the eye. In a preliminary experiment, we tested our antibody in a human donor eye and detected Hsp70 in all retinal layers except the RPE. This could indicate a wider role of heat shock proteins in retinal physiology, but could also be due to retinal changes in a dying human, especially to a breakdown of the blood-retina barrier. Lafaut et al. [13] showed that the majority of classic CNV membranes in AMD patients consisted of subretinal, fibrovascular tissue and independent of the underlying disease, CNV membranes exhibit similar histological feature and can be seen as the result of unspecific proliferation of fibrovascular tissue. CNV membranes in our study showed similar histological features described by Lafaut [13], including the presence of sporadic vessels, in which the endothelium was positive for Hsp70.

Desmettre et al. [11] demonstrated an upregulation of heat shock proteins in the chorioretinal layers 24 hours after TTT treatment in a rabbit model. Unfortunately we had available only two membranes from patients that had previously been treated with TTT treatment and in addition the membranes were surgically excised weeks following TTT and it is therefore not possible to make any assessment as to whether 


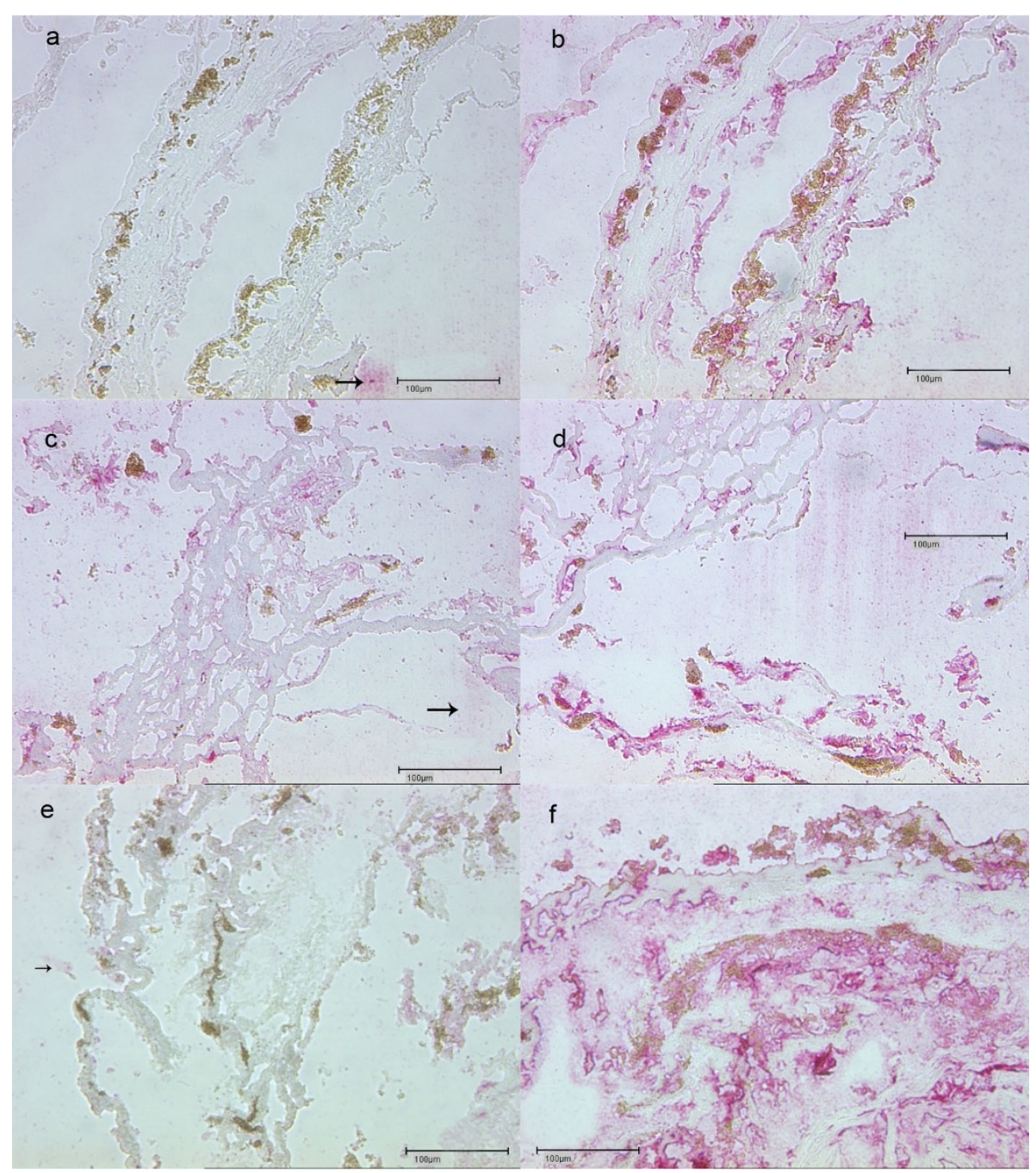

Figure 4 CNV membranes with PDT-/TTT- and non- pretreatment. PDT pretreated. a) PDT pretreated membrane which mostly consists of a fibrovascular. tissue architecture. No immunoreactivity (negative control) without primary antibody (Anti Hsp70, magnification $20 \mathrm{x}$ ). The surrounding pink staining reaction is an artefact (arrow). b) PDT pretreated membrane with immunoreactivity to the anti-Hsp70 primary antibody (pink stained tissue). TाT pretreated. c) TाT pretreated membrane which mostly consists of a fibrovascular tissue architecture. No immunoreactivity (negative control) without primary antibody (Anti Hsp70, magnification 20x). The surrounding pink staining reaction is an artefact (arrow). d) TTT pretreated membrane with immunoreactivity to anti Hsp70 (pink stained tissue). No pretreatment. e) Non pretreated membrane which mostly consists of a fibrovascular tissue architecture. No immunoreactivity (negative control). Without primary antibody (Anti Hsp70, magnification $20 \mathrm{x}$ ). The surrounding pink staining reaction is an artefact (arrow). f) Immunoreactivity to anti-HSP70 antibody of an untreated CNV membrane (pink stained tissue).

TTT treatment in humans upregulates heat shock proteins.

\section{Consent}

The study was performed with informed consent and following all the guidelines for experimental investigations required by the Institutional Review Board or Ethics Committee.

\section{Acknowledgments}

Supported by a grant (TV-B109) from the Interdisciplinary Centre for Clinical Research "BIOMAT." within the faculty of Medicine at the RWTH Aachen University and a grant by the START program of the medical faculty of the RWTH Aachen University.

\section{Author details}

${ }^{1}$ RWTH Aachen University, Department of Ophthalmology, Pauwelsstr. 30, 52074 Aachen, Germany. ${ }^{2}$ Augenklinik Starnberg, Josef-Jägerhuber-Str.7, 82319 Starnberg, Germany. 


\section{Authors' contributions}

APWJ: carried out histochemistry, histology and prepared a draft of the manuscript. DC: carried out histology and standardized immunostaining tests. GT: harvested CNV membranes, drafted and edited the manuscript. PW: harvested CNV membranes, drafted MS. AWAW: designed and coordinated study. All authors read and approved the final manuscript.

\section{Competing interests}

The authors declare that they have no competing interests.

Received: 23 September 2010 Accepted: 8 April 2011

Published: 8 April 2011

\section{References}

1. Bressler NM, Bressler SB, Fine SL: Age-related macular degeneration. Surv Ophthalmol 1988, 6:375-413.

2. Pauleikhoff D, Holz FG: Age-related macular degeneration. 1. Epidemiology, pathogenesis and differential diagnosis. Ophthalmologe 1996, 3:299-315.

3. Rosenfeld PJ, Brown DM, Heier JS, et al: MARINA Study Group. Ranibizumab for neovascular age-related macular degeneration. N Engl J Med 2006, 355:1419-1431.

4. Ghazi NG, Kirk TQ, Knape RM, Tiedeman JS, Conway BP: Is monthly retreatment with intravitreal bevacizumab (Avastin) necessary in neovascular age-related macular degeneration? Clin Ophthalmol 2010, 4:307-14.

5. Dean DO, Kent CR, Tytell M: Constitutive and inducible heat shock protein 70 immunoreactivity in the normal rat eye. Invest Ophthalmol Vis Sci 1999, 12:2952-62.

6. Walter S, Buchner J: Molecular chaperones-cellular machines for protein folding. Angewandte Chemie (International ed. in English) 2002, 41:1098-113.

7. Borges JC, Ramos $\mathrm{CH}$ : Protein folding assisted by chaperones. Protein and peptide letters 2005, 12:257-61.

8. Wegele H, Müller L, Buchner J: Hsp70 and Hsp90 - a relay team for protein folding. Rev. Physiol. Biochem. Pharmacol 2004, 151:1-44.

9. Beere HM, Wolf BB, Cain K, Mosser DD, Mahboubi A, Kuwana T, Tailor P, Morimoto Rl, Cohen GM, Green DR: eat-shock protein 70 inhibits apoptosis by preventing recruitment of procaspase- 9 to the Apaf-1 apoptosome". Nat. Cell Biol 2000, 2:469-75.

10. Mainster MA, Reichel E: Transpupillary thermotherapy for age-related macular degeneration: long-pulse photocoagulation, apoptosis, and heat shock proteins. Ophthalmic Surg Lasers 2000, 5:359-73.

11. Desmettre T, Maurage CA, Mordon S: Heat shock protein hyperexpression on chorioretinal layers after transpupillary thermotherapy. Invest Ophthalmol Vis Sci 2001, 12:2976-80.

12. Dean DO, Tytell M: Hsp25 and -90 immunoreactivity in the normal rat eye. Invest Ophthalmol Vis Sci 2001, 12:3031-40.

13. Lafaut BA, Bartz-Schmidt KU, Vanden Broecke C, Aisenbrey S, De Laey JJ, Heimann K: Clinicopathological correlation in exudative age related macular degeneration: histological differentiation between classic and occult choroidal neovascularisation. Br J Ophthalmol 2000, 3:239-43.

\section{doi:10.1186/1756-0500-4-115}

Cite this article as: Jöres et al.: Detection of heat shock protein 70 in choroidal neovascular membranes secondary to age related macular degeneration. BMC Research Notes 2011 4:115.

\section{Submit your next manuscript to BioMed Central and take full advantage of:}

- Convenient online submission

- Thorough peer review

- No space constraints or color figure charges

- Immediate publication on acceptance

- Inclusion in PubMed, CAS, Scopus and Google Scholar

- Research which is freely available for redistribution

Submit your manuscript at www.biomedcentral.com/submit
Biomed Central 